\title{
Selection of Differential Isolates of Magnaporthe oryzae for Postulation of Blast Resistance Genes
}

\author{
W. W. Fang, C. C. Liu, H. W. Zhang, H. Xu, S. Zhou, K. X. Fang, Y. L. Peng, and W. S. Zhao
}

First, second, third, fifth, sixth, seventh, and eighth authors: State Key Laboratory of Agrobiotechnology and MOA Key Lab of Pest Monitoring and Green Management, China Agricultural University, Beijing 100193, China; and fourth author: Institute of Plant Protection, Liaoning Academy of Agricultural Sciences, Shenyang 110161, China.

Accepted for publication 26 January 2018.

\begin{abstract}
A set of differential isolates of Magnaporthe oryzae is needed for the postulation of blast resistance genes in numerous rice varieties and breeding materials. In this study, the pathotypes of 1,377 M. oryzae isolates from different regions of China were determined by inoculating detached rice leaves of 24 monogenic lines. Among them, 25 isolates were selected as differential isolates based on the following characteristics: they had distinct responses on the monogenic lines, contained the minimum number of avirulence genes, were stable in pathogenicity and conidiation

during consecutive culture, were consistent colony growth rate, and, together, could differentiate combinations of the 24 major blast resistance genes. Seedlings of rice cultivars were inoculated with this differential set of isolates to postulate whether they contain 1 or more than 1 of the 24 blast resistance genes. The results were consistent with those from polymerase chain reaction analysis of target resistance genes. Establishment of a standard set of differential isolates will facilitate breeding for blast resistance and improved management of rice blast disease.
\end{abstract}

Rice blast, caused by the ascomycete fungus Magnaporthe oryzae, is one of the most devastating diseases worldwide (Dai et al. 2010; Ou 1980; Valent 1990; Wilson and Talbot 2009) and can cause yield losses ranging from 20 to $50 \%$ (Huang et al. 2014; Savary et al. 2000). The interactions between blast fungus (Ling et al. 2004) and rice have been considered to follow the genefor-gene hypothesis ( $\mathrm{Li}$ et al. 2009). The most effective and economically viable approach to control blast disease is to plant cultivars that have major blast resistance $(R)$ genes (Valent and Chumley 1991; Zhu et al. 2000). This disease management strategy is effective only when the deployed cultivars that carry major $R$ genes are infected by the strains of $M$. oryzae population that contain the corresponding avirulence $(A V R)$ genes. However, the resistance mediated by major genes may be overcome (Zeigler et al. 1994) by new virulent races shortly after deployment as a result of rapidly evolving $M$. oryzae populations (Bonman et al. 1992). Therefore, deployment of blast resistance cultivars requires monitoring of the dynamics of races or gaining information on the current and future frequency of $A V R$ genes in $M$. oryzae populations because it is not practicable to track numerous races at the same time. During the past few decades, huge efforts have been made in this direction. Commonly, this was done by sampling isolates from $M$. oryzae populations and inoculating them onto a set of differential rice varieties (Levy et al. 1993). The differential varieties used in this work also evolved, from rice cultivars with complex genetic background to monogenic lines, and from local various differentials used by particular research groups to an internationally shared set of monogenic lines. These latter lines

${ }^{\dagger}$ Corresponding author: W. S. Zhao; E-mail: mppzhaws@cau.edu.cn

Funding: This work was financed by Project 201203014 from the Special Scientific Research Fund of Agricultural Public Welfare Profession and Project CARS-01 from National Rice Industry System of China.

W. W. Fang and C. C. Liu contributed equally to this work.

C 2018 The American Phytopathological Society have been developed by the International Rice Research Institute (IRRI) -Japan Collaborative Research Project and are composed of 31 monogenic lines carrying 24 major blast $R$ genes (Kobayashi et al. 2007; Tsunematsu et al. 2000). A Japonica-type variety, Lijiangxintuanheigu (LTH), found in Yunnan province and highly susceptible to all of the evaluated blast isolates (Ling et al. 2001), has been used as the recurrent female parent, and varieties with known $R$ gene(S) have been used as donors in development of this set of differentials. These monogenic lines with the genetic background of LTH were the first international standard differential varieties to monitor the pathotypes of blast isolates. The results from different research groups revealed that the rice blast fungal populations have a complex genetic background (Choi et al. 2013; Xue et al. 2012; Zhang et al. 2016) and huge numbers of physiological races (Le et al. 2010; Odjo et al. 2014). In the previous work, an accurate, rapid, and large-scale wounding inoculation method was established to identify the pathotypes of M. oryzae (Zhang et al. 2014).

Successful management of rice blast via deployment of resistant varieties requires not only information on pathogen populations but also a large number of varieties with desired $R$ genes, to deploy blast-resistant rice cultivars to match their $R$ genes with the highfrequency $A V R$ genes in the pathogen population. Some efforts have been made in postulation of blast $R$ genes carried in cultivars to be deployed and in breeding materials which provide the basis of $R$ genes for future cultivars (Deng et al. 2017; Shi et al. 2015; Wang et al. 2017). According to the gene-for-gene hypothesis, an $R$ gene in a host can only be revealed from its reaction to pathogen isolates carrying the corresponding $A V R$ gene.

Postulation of blast resistance genotypes was usually done by inoculating the test cultivars with unknown resistance genotypes and the differential monogenic lines with selected isolates, and then comparing their reactions to the isolates with those on differential monogenic lines (Ling 1984, Ling et al. 1990). It has long been recognized that the key to $R$ gene postulation is selection of appropriate isolates. However, thus far, due to lack of an established set of differential isolates, individual researchers have had to start from scratch by screening isolates and then using them in inoculation tests. Screening of proper isolates is time consuming, 
labor intensive, and often not successful due to limited availability of discriminatory isolates. The lack of the appropriate isolates has slowed the postulation of blast $R$ genes in rice cultivars and breeding materials, and using different isolate sets also makes it difficult to compare results from different studies.

Molecular tools have also been developed for postulation of blast $R$ genes in a cultivar during the past decades (Jeung et al. 2007). To date, $24 R$ genes have been cloned (Liu et al. 2015). With the advance of bulked segregant analysis and, more recently, nextgeneration sequencing techniques, whether a cultivar carries these major $R$ genes can be determined with molecular techniques quickly. However, molecular methods have some limitation in identifying $R$ genes. First, transposable element (TE) insertions, TE-mediated genome reorganization, and TE-associated methylation evolution (Takahashi et al. 2010) make it difficult to determine whether an $R$ gene functions or not solely based on sequencing of a small DNA fragment. Compared with the nonfunctional allele $P i t^{N p b}$, the functional allele $P i t^{K 59}$ contains four amino acid substitutions, and has the long terminal repeat retrotransposon renovator inserted upstream (Hayashi and Yoshida 2009). Moreover, the extremely similar sequence among different functional $R$ genes such as alleles at Pi2/9 (Su et al. 2015) makes it difficult to develop gene-specific markers for determining known genes from diverse varieties. Few single nucleotide polymorphisms (SNPs) of $R$ genes could lead to differences in the function; for example, the resistance specificities of $\mathrm{Pi}, \mathrm{Pi}$, and $\mathrm{Piz}^{t}$ are determined by a few amino acid changes (Zhou et al. 2006). Therefore, inoculation will be a useful method for identifying $R$ genes against rice blast for a long time in the future.

In this study, our objectives were to select a set of differential isolates for postulation of blast $R$ genes in rice varieties, to make better use of those varieties.

\section{MATERIALS AND METHODS}

Ideal differential isolates should have the following characteristics: (i) stable, with little variation in growth rate and conidiation; (ii) distinct reactions on susceptible and resistant monogenic lines; (iii) each isolate containing as few $A V R$ gene(S) as possible, ideally a single $A V R$ gene; and (iv) when used together, they can differentiate all of the possible combinations of the 24 major $R$ genes in the international differential monogenic lines. Therefore, our efforts were concentrated on these four aspects.

Plant materials and isolates. The 24 monogenic lines developed from LTH, which was considered susceptible to all isolates of M. oryzae (Kobayashi et al. 2007; Ling et al. 2001; Tsunematsu et al. 2000), were used as differential varieties to screen isolates of M. oryzae (Table 1), and LTH was also included as a susceptible control. Seeds of all of these lines were planted in silty clay soil in plastic pots ( 40 by 20 by $5 \mathrm{~cm}$ ) with holes at the bottom, maintained in the greenhouse at approximately $26^{\circ} \mathrm{C}$ and $70 \%$ relative humidity, with a regime of $14 \mathrm{~h} /$ day and $10 \mathrm{~h} /$ night, and watered regularly. At the four- to five-leaf stage (3-week-old seedings), the middle and upper leaves of LTH and 24 monogenic lines were detached and transferred into the lab for inoculation.

Isolates of $M$. oryzae were obtained via single-spore isolation from diseased leaves of LTH plants grown in Farm 856 in Heilongjiang Province and Donggang and Dawa in Liaoning Province during 2010 to 2014. In total, 1,377 single-spore isolates, including 451, 529, and 397 isolates from Farm 856, Donggang, and Dawa, respectively, were used for screening in this study (Table 2).

Isolates of $M$. oryzae were maintained on oatmeal tomato agar (OTA) (30 to $40 \mathrm{~g}$ of oatmeal, $20 \mathrm{~g}$ of agar, $150 \mathrm{ml}$ of tomato juice, and approximately $850 \mathrm{ml}$ of $\mathrm{H}_{2} \mathrm{O}$ ) (Yang et al. 2010) at $26^{\circ} \mathrm{C}$ and further subcultured onto new OTA plates. For long-term storage, autoclaved filter paper discs ( $1 \mathrm{~cm}$ in diameter) were placed on the growing colony for 7 days to allow the pathogen hyphae to cover the discs; then, the discs were collected in a sulphuric acid paper bag, air dried, and stored at $-20^{\circ} \mathrm{C}$.
Inoculation of differential monogenic lines and LTH with isolates of $M$. oryzae. The 7-day-old OTA colonies of the $M$. oryzae isolates were induced to produce conidia, which were harvested and used to prepare inoculum as described previously (Peng and Shishiyama 1988). The detached leaves were cut into 5to 7-cm leaf fragments, placed in a $90-\mathrm{mm}$ Petri dish, scratched using a pin along the main vein ( 2 by $2 \mathrm{~mm}$ ), and inoculated with a drop of $10 \mu$ of conidium suspension of $1 \times 10^{5}$ spores $/ \mathrm{ml}$ in $0.025 \%$ Tween 20 solution (Zhang et al. 2014). The three inoculated leaf fragments were sealed in a Petri dish and incubated in darkness at $90 \%$ relative humidity for 24 to $36 \mathrm{~h}$ before being transferred to a chamber maintained at $26^{\circ} \mathrm{C}$. The reactions were examined and photographed at 4 to 7 days postinoculation (dpi). The reaction

TABLE 1. Monogenic lines with different resistance genes

\begin{tabular}{|c|c|c|c|c|}
\hline Code & $\begin{array}{c}\text { Monogenic } \\
\text { line }\end{array}$ & $\begin{array}{c}\text { Resistance } \\
\text { gene }\end{array}$ & Donor & Origin \\
\hline K01 & IRBLa-A & Pia & Aichi Asahi & Philippines \\
\hline K03 & IRBLi-F5 & Pii & Fujisaki5 & Philippines \\
\hline K04 & IRBLks-F5 & $P i k^{s}$ & Fujisaki5 & Philippines \\
\hline K06 & IRBLk-Ka & Pik & Kanto51 & Philippines \\
\hline K07 & IRBLkp-K60 & $P i k^{p}$ & K60 & Philippines \\
\hline K08 & IRBLkh-K3 & $P i k^{h}$ & $\mathrm{~K} 3$ & Philippines \\
\hline K09 & IRBLz-Fu & $\mathrm{Piz}$ & Fukunishiki & Philippines \\
\hline K10 & IRBLz5-CA & $P i z^{5}$ & C101A51 & Philippines \\
\hline K11 & IRBLzt-T & $P_{i z^{t}}$ & Toride 1 & Philippines \\
\hline K12 & IRBLta-K1 & Pita & $\mathrm{K} 1$ & Philippines \\
\hline K14 & IRBLb-B & $P i b$ & BL1 & Philippines \\
\hline K15 & IRBLt-K59 & Pit & K59 & Philippines \\
\hline K17 & IRBLsh-B & Pish & BL1 & Philippines \\
\hline K18 & IRBL1-CL & Pi1 & C101LAC & Philippines \\
\hline K19 & IRBL3-CP4 & Pi3 & C104PKT & Philippines \\
\hline $\mathrm{K} 20$ & IRBL5-M & Pi5 & Moroberekan(RIL249) & Philippines \\
\hline K21 & IRBL7-M & Pi7 & Moroberekan(RIL29) & Philippines \\
\hline $\mathrm{K} 22$ & IRBL9-W & Pi9 & WHD-1S-75-1-127 & Philippines \\
\hline $\mathrm{K} 23$ & IRBL12-M & Pi12 & Moroberekan(RIL10) & Philippines \\
\hline K24 & IRBL19-M & Pil9 & Aichi Asahi & Philippines \\
\hline $\mathrm{K} 25$ & IRBLkm-Ts & $P i k^{m}$ & Tsuyuake & Philippines \\
\hline K26 & IRBL20-IR24 & Pi20 & ARL24 & Philippines \\
\hline K27 & IRBLta2-Pi & Pita2 & Pi No.4 & Philippines \\
\hline K30 & IRBL11-Zh & Pil1 & Zhaiyeqing 8 & Philippines \\
\hline
\end{tabular}

TABLE 2. Origins of field isolates used in this study

\begin{tabular}{lcrrrrrr}
\hline & & \multicolumn{4}{c}{ Number of isolates by year } & \multirow{2}{*}{ Total } \\
\cline { 3 - 6 } Location & GPS & 2010 & 2011 & 2012 & 2013 & 2014 & isolates \\
\hline Farm 856 & $45.62^{\circ} \mathrm{N}, 132.72^{\circ} \mathrm{E}$ & 96 & 99 & 66 & 90 & 100 & 451 \\
Donggang & $39.54^{\circ} \mathrm{N}, 124.08^{\circ} \mathrm{E}$ & 126 & 89 & 107 & 89 & 118 & 529 \\
Dawa & $41.02^{\circ} \mathrm{N}, 122.04^{\circ} \mathrm{E}$ & 0 & 100 & 95 & 90 & 112 & 397 \\
\hline
\end{tabular}

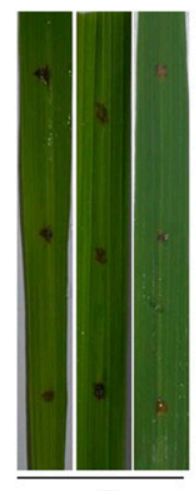

$\mathbf{R}$

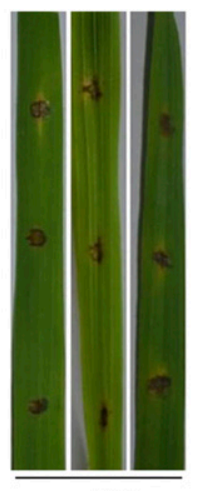

MR

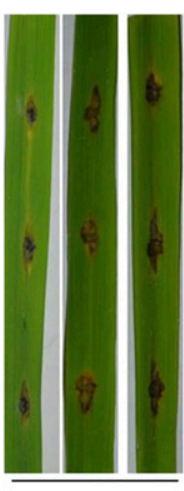

MS

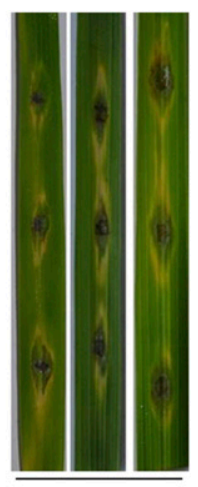

$\mathbf{S}$
Fig. 1. Reaction types of field isolates on monogenic lines: resistant (R), moderately resistant (MR), moderately susceptible (MS), and susceptible (S). 
types were scaled as one of four categories: resistant reaction $(\mathrm{R})$, moderately resistant reaction (MR), moderately susceptible reaction (MS), and susceptible reaction (S) (Fig. 1). In the R reaction, the lesions were dark brown and restricted to the wounded area without distinctive center. In the MR reaction, the biggest lesion was less than $3 \mathrm{~mm}$ long whereas, in the MS reaction, the biggest lesion was more than $3 \mathrm{~mm}$ long. In $\mathrm{S}$ reactions, the lesions were spindle shaped, with gray centers, brown margins, and yellow haloes.

Identification of $\boldsymbol{A} \boldsymbol{V} \boldsymbol{R}$ genes. In gene-for-gene systems, a resistance reaction of a plant to a pathogen is due to the "recognition" by the plant surveillance system of a pathogen $A V R$ determinant encoded by an $A V R$ gene to eventually result in triggering of plant

TABLE 3. Matrix of the preliminary candidate isolates and the data of their growth rate and conidiation ${ }^{\mathrm{a}}$

\begin{tabular}{|c|c|c|c|c|c|c|c|c|c|c|c|c|c|c|c|c|c|c|c|c|c|c|c|c|c|c|}
\hline Isolate & Pita2 & $P i z^{t}$ & Pil9 & Pi20 & Pita & $\mathrm{Pi7}$ & $P i k^{m}$ & $P i z^{5}$ & $P i k^{s}$ & Pit & Pi3 & Pii & $P i 9$ & Pish & Pil & Pi5 & $P i k$ & $P i k^{p}$ & Pia & Pill & $P i b$ & $P i k^{h}$ & Pi12 & $\mathrm{Piz}$ & $\begin{array}{c}\text { Colony } \\
\text { diameter (mm) }\end{array}$ & $\begin{array}{c}\log _{10} \\
\text { (conidiation) }\end{array}$ \\
\hline $10-856-44$ & 0 & 0 & 0 & 0 & 0 & 0 & 0 & 0 & 0 & 0 & 0 & 0 & 0 & 0 & 0 & 0 & 0 & 0 & 0 & 0 & 0 & 0 & 0 & 0 & $34.7 \pm 0.6$ & $6.69 \pm 0.07$ \\
\hline $10-856-33$ & 1 & 0 & 0 & 0 & 0 & 0 & 0 & 0 & 0 & 0 & 0 & 0 & 0 & 0 & 0 & 0 & 0 & 0 & 0 & 0 & 0 & 0 & 0 & 0 & $36.1 \pm 0.5$ & $5.96 \pm 0.27$ \\
\hline $11-856-35$ & 0 & 1 & 0 & 0 & 0 & 0 & 0 & 0 & 0 & 0 & 0 & 0 & 0 & 0 & 0 & 0 & 0 & 0 & 0 & 0 & 0 & 0 & 0 & 0 & $34.4 \pm 0.5$ & $6.53 \pm 0.06$ \\
\hline $10-856-37$ & 0 & 0 & 1 & 0 & 0 & 0 & 0 & 0 & 0 & 0 & 0 & 0 & 0 & 0 & 0 & 0 & 0 & 0 & 0 & 0 & 0 & 0 & 0 & 0 & $34.0 \pm 1.1$ & $6.47 \pm 0.12$ \\
\hline $13-856-39$ & 0 & 0 & 0 & 1 & 0 & 0 & 0 & 0 & 0 & 0 & 0 & 0 & 0 & 0 & 0 & 0 & 0 & 0 & 0 & 0 & 0 & 0 & 0 & 0 & $35.6 \pm 0.9$ & $6.44 \pm 0.05$ \\
\hline $10-856-41$ & 0 & 0 & 0 & 0 & 1 & 0 & 0 & 0 & 0 & 0 & 0 & 0 & 0 & 0 & 0 & 0 & 0 & 0 & 0 & 0 & 0 & 0 & 0 & 0 & $36.4 \pm 0.7$ & $5.73 \pm 0.20$ \\
\hline $10-856-32$ & 0 & 0 & 0 & 0 & 0 & 1 & 0 & 0 & 0 & 0 & 0 & 0 & 0 & 0 & 0 & 0 & 0 & 0 & 0 & 0 & 0 & 0 & 0 & 0 & $35.3 \pm 0.7$ & $6.30 \pm 0.05$ \\
\hline 13-DG-17 & 0 & 0 & 0 & 0 & 0 & 1 & 0 & 0 & 0 & 0 & 0 & 0 & 0 & 0 & 0 & 0 & 0 & 0 & 0 & 0 & 0 & 0 & 0 & 0 & $34.7 \pm 1.0$ & $5.62 \pm 0.15$ \\
\hline $10-856-57$ & 0 & 0 & 0 & 0 & 0 & 0 & 1 & 0 & 0 & 0 & 0 & 0 & 0 & 0 & 0 & 0 & 0 & 0 & 0 & 0 & 0 & 0 & 0 & 0 & $34.3 \pm 0.4$ & $6.24 \pm 0.07$ \\
\hline $14-856-47$ & 0 & 0 & 0 & 0 & 0 & 0 & 1 & 0 & 0 & 0 & 0 & 0 & 0 & 0 & 0 & 0 & 0 & 0 & 0 & 0 & 0 & 0 & 0 & 0 & $34.1 \pm 0.6$ & $5.88 \pm 0.09$ \\
\hline 11-PJ-12 & 0 & 0 & 0 & 0 & 0 & 0 & 1 & 0 & 0 & 0 & 0 & 0 & 0 & 0 & 0 & 0 & 0 & 0 & 0 & 0 & 0 & 0 & 0 & 0 & $34.4 \pm 0.3$ & $5.62 \pm 0.15$ \\
\hline $11-856-07$ & 0 & 0 & 0 & 0 & 0 & 0 & 0 & 1 & 0 & 0 & 0 & 0 & 0 & 0 & 0 & 0 & 0 & 0 & 0 & 0 & 0 & 0 & 0 & 0 & $34.0 \pm 0.6$ & $6.33 \pm 0.11$ \\
\hline $11-856-19$ & 0 & 0 & 0 & 0 & 0 & 0 & 0 & 0 & 1 & 0 & 0 & 0 & 0 & 0 & 0 & 0 & 0 & 0 & 0 & 0 & 0 & 0 & 0 & 0 & $36.2 \pm 0.6$ & $6.85 \pm 0.03$ \\
\hline $11-856-10$ & 0 & 0 & 0 & 0 & 0 & 0 & 0 & 0 & 1 & 0 & 0 & 0 & 0 & 0 & 0 & 0 & 0 & 0 & 0 & 0 & 0 & 0 & 0 & 0 & $32.7 \pm 0.8$ & $6.36 \pm 0.06$ \\
\hline $12-856-02$ & 0 & 0 & 0 & 0 & 0 & 0 & 0 & 0 & 1 & 0 & 0 & 0 & 0 & 0 & 0 & 0 & 0 & 0 & 0 & 0 & 0 & 0 & 0 & 0 & $34.4 \pm 0.4$ & $6.14 \pm 0.09$ \\
\hline $11-856-12$ & 0 & 0 & 0 & 0 & 0 & 0 & 0 & 0 & 0 & 1 & 0 & 0 & 0 & 0 & 0 & 0 & 0 & 0 & 0 & 0 & 0 & 0 & 0 & 0 & $35.9 \pm 0.9$ & $6.51 \pm 0.07$ \\
\hline $11-856-25$ & 0 & 0 & 0 & 0 & 0 & 0 & 0 & 0 & 0 & 0 & 1 & 0 & 0 & 0 & 0 & 0 & 0 & 0 & 0 & 0 & 0 & 0 & 0 & 0 & $40.9 \pm 0.6$ & $6.88 \pm 0.03$ \\
\hline 13-DG-44 & 0 & 0 & 0 & 0 & 0 & 0 & 0 & 0 & 0 & 0 & 1 & 0 & 0 & 0 & 0 & 0 & 0 & 0 & 0 & 0 & 0 & 0 & 0 & 0 & $35.7 \pm 0.4$ & $5.82 \pm 0.16$ \\
\hline $11-856-70$ & 0 & 0 & 0 & 0 & 0 & 0 & 0 & 0 & 0 & 0 & 0 & 1 & 0 & 0 & 0 & 0 & 0 & 0 & 0 & 0 & 0 & 0 & 0 & 0 & $40.2 \pm 0.3$ & $6.60 \pm 0.08$ \\
\hline $11-856-79$ & 0 & 0 & 0 & 0 & 0 & 0 & 0 & 0 & 0 & 0 & 0 & 0 & 1 & 0 & 0 & 0 & 0 & 0 & 0 & 0 & 0 & 0 & 0 & 0 & $39.1 \pm 0.3$ & $6.00 \pm 0.14$ \\
\hline $14-856-79$ & 0 & 0 & 0 & 0 & 0 & 0 & 0 & 0 & 0 & 0 & 0 & 0 & 1 & 0 & 0 & 0 & 0 & 0 & 0 & 0 & 0 & 0 & 0 & 0 & $35.6 \pm 0.4$ & $5.68 \pm 0.15$ \\
\hline 13-DG-36 & 0 & 0 & 0 & 0 & 0 & 0 & 0 & 0 & 0 & 0 & 0 & 0 & 1 & 0 & 0 & 0 & 0 & 0 & 0 & 0 & 0 & 0 & 0 & 0 & $36.6 \pm 0.6$ & $6.17 \pm 0.07$ \\
\hline 12-DG-36 & 0 & 0 & 0 & 0 & 0 & 0 & 0 & 0 & 0 & 0 & 0 & 0 & 1 & 0 & 0 & 0 & 0 & 0 & 0 & 0 & 0 & 0 & 0 & 0 & $35.5 \pm 0.5$ & $5.95 \pm 0.12$ \\
\hline $11-856-74$ & 0 & 0 & 0 & 0 & 0 & 0 & 0 & 0 & 0 & 0 & 0 & 0 & 0 & 1 & 0 & 0 & 0 & 0 & 0 & 0 & 0 & 0 & 0 & 0 & $35.8 \pm 0.2$ & $5.67 \pm 0.15$ \\
\hline $10-856-16$ & 0 & 0 & 0 & 0 & 0 & 0 & 0 & 0 & 0 & 0 & 0 & 0 & 0 & 0 & 1 & 0 & 0 & 0 & 0 & 0 & 0 & 0 & 0 & 0 & $36.3 \pm 1.0$ & $5.62 \pm 0.15$ \\
\hline $11-856-97$ & 0 & 0 & 0 & 0 & 0 & 0 & 0 & 0 & 0 & 0 & 0 & 0 & 0 & 0 & 0 & 1 & 0 & 0 & 0 & 0 & 0 & 0 & 0 & 0 & $36.7 \pm 0.8$ & $6.48 \pm 0.10$ \\
\hline $11-856-58$ & 0 & 0 & 0 & 0 & 0 & 0 & 0 & 0 & 0 & 0 & 0 & 0 & 0 & 0 & 0 & 0 & 1 & 0 & 0 & 0 & 0 & 0 & 0 & 0 & $29.2 \pm 0.8$ & $6.62 \pm 0.08$ \\
\hline $11-856-59$ & 0 & 0 & 0 & 0 & 0 & 0 & 0 & 0 & 0 & 0 & 0 & 0 & 0 & 0 & 0 & 0 & 0 & 1 & 0 & 0 & 0 & 0 & 0 & 0 & $39.3 \pm 0.4$ & $6.97 \pm 0.03$ \\
\hline $11-856-48$ & 0 & 0 & 0 & 0 & 0 & 0 & 0 & 0 & 0 & 0 & 0 & 0 & 0 & 0 & 0 & 0 & 0 & 0 & 1 & 0 & 0 & 0 & 0 & 0 & $39.6 \pm 0.4$ & $7.27 \pm 0.02$ \\
\hline $11-856-52$ & 0 & 0 & 0 & 0 & 0 & 0 & 0 & 0 & 0 & 0 & 0 & 0 & 0 & 0 & 0 & 0 & 0 & 0 & 0 & 1 & 0 & 0 & 0 & 0 & $38.0 \pm 0.2$ & $7.17 \pm 0.03$ \\
\hline $10-856-63$ & 0 & 0 & 0 & 0 & 0 & 0 & 0 & 0 & 0 & 0 & 0 & 0 & 0 & 0 & 0 & 0 & 0 & 0 & 0 & 1 & 0 & 0 & 0 & 0 & $36.2 \pm 0.2$ & $6.71 \pm 0.03$ \\
\hline $13-856-56$ & 0 & 0 & 0 & 0 & 0 & 0 & 0 & 0 & 0 & 0 & 0 & 0 & 0 & 0 & 0 & 0 & 0 & 0 & 0 & 0 & 1 & 0 & 0 & 0 & $39.4 \pm 0.5$ & $6.94 \pm 0.03$ \\
\hline 11-PJ-40 & 0 & 0 & 0 & 0 & 0 & 0 & 0 & 0 & 0 & 0 & 0 & 0 & 0 & 0 & 0 & 0 & 0 & 0 & 0 & 0 & 0 & 1 & 0 & 0 & $36.0 \pm 0.2$ & $7.17 \pm 0.03$ \\
\hline $12-856-64$ & 0 & 0 & 0 & 0 & 0 & 0 & 0 & 0 & 0 & 0 & 0 & 0 & 0 & 0 & 0 & 0 & 0 & 0 & 0 & 0 & 0 & 0 & 1 & 0 & $38.6 \pm 0.8$ & $6.73 \pm 0.04$ \\
\hline $11-856-49$ & 0 & 0 & 0 & 0 & 0 & 0 & 0 & 0 & 0 & 0 & 0 & 0 & 0 & 0 & 0 & 0 & 0 & 0 & 0 & 0 & 0 & 0 & 1 & 0 & $37.4 \pm 0.4$ & $6.09 \pm 0.09$ \\
\hline $13-856-53$ & 0 & 0 & 0 & 0 & 0 & 0 & 0 & 0 & 0 & 0 & 0 & 0 & 0 & 0 & 0 & 0 & 0 & 0 & 0 & 0 & 0 & 0 & 0 & 1 & $38.0 \pm 0.6$ & $6.62 \pm 0.04$ \\
\hline $11-856-21$ & 0 & 0 & 0 & 0 & 0 & 0 & 0 & 0 & 0 & 0 & 0 & 0 & 0 & 0 & 0 & 0 & 0 & 0 & 0 & 0 & 0 & 0 & 0 & 1 & $37.8 \pm 0.5$ & $6.36 \pm 0.06$ \\
\hline
\end{tabular}

a Reactions: $0=$ susceptible and $1=$ resistant. Lijiangxintuanheigu was susceptible to all of the assayed isolates.

TABLE 4. Matrix of avirulence genotypes of differential isolates ${ }^{\mathrm{a}}$

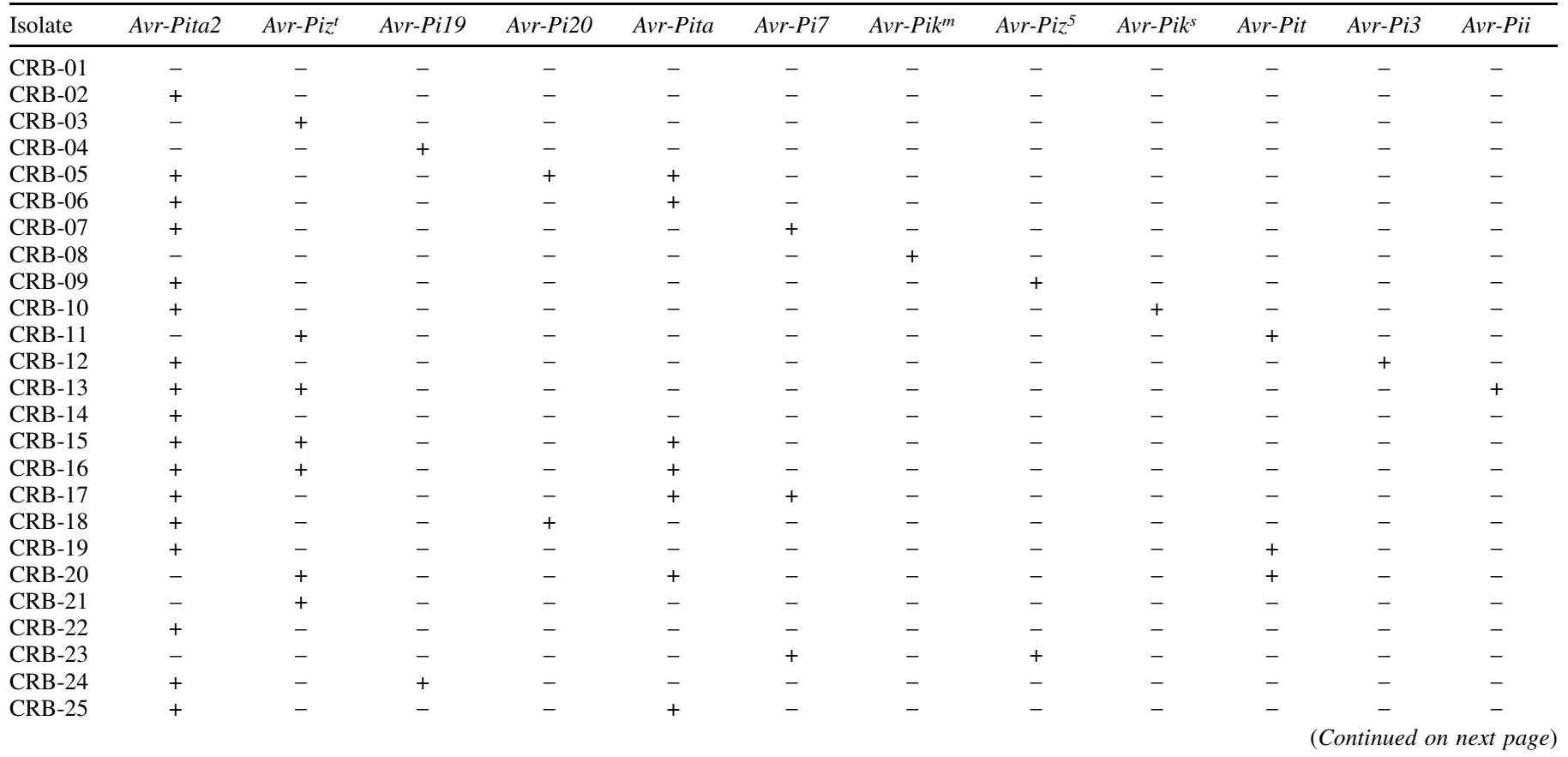

a Symbols: + and - indicate that the isolate contains or does not contain, respectively, the avirulence gene in the top line. 
immunity. Therefore, if an isolate resulted in resistance reaction on a monogenic line that carries a single major $R$ gene in the inoculation, then we determined that the tested isolate contains the corresponding $A V R$ gene; otherwise, it does not contain the $A V R$ gene when reaction was susceptible. In this way, the $A V R$ genes of all 1,377 isolates were identified based on their R or S reactions on the 24 monogenic lines and LTH.

Preliminary selection of candidate differential isolates. First, a matrix was constructed for the reactions of all 1,377 isolates on the 24 monogenic lines and LTH, with each isolate as a row. To avoid inconsistent or ambiguous reactions, all of the rows with MR and MS were removed; then, $\mathrm{R}$ and $\mathrm{S}$ reactions were converted into " 1 " and " 0 ", respectively, and a column ("Sum") of row sum was added to the right to store the total number of $A V R$ genes carried by each isolate. The rows with a value greater than 6 were removed to minimize the number of $A V R$ genes carried by selected isolates. The following row and column transformations were done on the matrix to search for a set of candidate isolates that, as a whole, can differentiate all possible combination of the 24 major $R$ genes carried by the monogenic lines:

1. Sorted the rows in order from the smallest to greatest "Sum";

2. Moved the whole column (other than "Sum") that had a value " 1 " in the top row that had a value " 1 " in column "Sum", and was in the area that was not yet arranged, into the left-most column that was not occupied by a " 1 " in the arranged area, and all rows from the top to this row were then considered arranged. If more than one row was exactly the same, then they were considered alternative choices; if there were multiple rows with sum " 1 " but their " 1 " values were not in the same column, all columns were moved;

3 . Changed the value of cells in nonarranged rows to " 0 " if there had already been a " 1 " in the same columns in the arranged area;

4. Recalculated the column "Sum" and repeated steps 1 through 3 until the top matrix (excluded the column "Sum" and alternative rows) became an identity matrix.

All of the isolates listed in the identity matrix and their alternatives were used as candidate isolates for the subsequent screen based on growth rate and conidiation.
Determination of growth rate and conidiation for all candidate isolates of $M$. oryzae. The candidate isolates selected from the above step were revived by plating the stored filter paper discs with mycelium on an OTA plate at $26^{\circ} \mathrm{C}$. When the colony covered two-thirds of the plate, a 5-mm-diameter mycelium plug was transferred onto the center of a new 6-cm-diameter OTA plate (approximately $15 \mathrm{ml}$ of medium). After incubation at $26^{\circ} \mathrm{C}$ for $120 \mathrm{~h}$ in a light incubator, the colony diameter was measured twice diagonally and the average diameter was calculated. The experiment was done three times, and the mean growth rates and their standard deviations were calculated. The standard deviation formula is as follows:

$$
\text { Standard deviation }=\sqrt{\frac{\sum\left(\mathrm{x}_{\mathrm{i}}-\overline{\mathrm{x}}\right)^{2}}{\mathrm{~N}-1}}
$$

where $\mathrm{N}=$ number of experiments $=3$.

Conidia were produced as previously described (Peng and Shishiyama 1988). Conidia were harvested from 10-day-old cultures on OTA using sterile distilled water and counted under a microscope with a hemocytometer. Three independent experiments were done, with three plates included in each experiment. After logtransformation, the means and their standard errors were calculated. Based on the production of conidia and colony growth rate, the candidate isolates were further narrowed down to 25 isolates that have a high growth rate and abundant conidial production.

Test of the stability of reaction type and conidiation for candidate isolates. The 25 candidate isolates were inoculated on 24 monogenic lines repeatedly at least three times over a 3-year period to confirm virulence, and the conidiation of these candidate isolates was also quantified. The mycelia of candidate isolates were stored at autoclaved filter paper discs at $-20^{\circ} \mathrm{C}$ during these 3 years and subcultured onto new OTA plates monthly.

\section{RESULTS}

Inoculation of isolates on monogenic lines and selection of candidate differential isolates. Our inoculation technique was efficient, in that all 1,377 field isolates assayed showed an S reaction on the susceptible control, LTH. Among them there were 7,

TABLE 4. (Continued from previous page)

\begin{tabular}{|c|c|c|c|c|c|c|c|c|c|c|c|}
\hline Avr-Pi9 & Avr-Pish & $A v r-P i 1$ & $A v r-P i 5$ & Avr-Pik & $A v r-P i k^{p}$ & Avr-Pia & $A v r-P i 11$ & $A v r-P i b$ & $A v r-P i k^{h}$ & Avr-Pi12 & Avr-Piz \\
\hline- & - & - & - & - & - & - & - & - & - & - & - \\
\hline- & - & - & - & - & - & - & - & - & - & - & - \\
\hline- & - & - & - & - & - & - & - & - & - & - & - \\
\hline- & - & - & - & - & - & - & - & - & - & - & - \\
\hline- & - & - & - & - & - & - & - & - & - & + & - \\
\hline- & - & - & - & - & - & - & - & - & - & - & - \\
\hline- & - & - & - & - & - & - & - & - & - & - & - \\
\hline- & - & - & - & - & + & + & - & - & - & - & - \\
\hline- & - & - & - & - & - & - & + & - & - & - & - \\
\hline- & - & - & - & - & - & - & - & - & - & - & + \\
\hline- & - & - & - & - & - & - & - & - & - & - & + \\
\hline- & - & - & - & - & - & - & + & - & - & - & - \\
\hline- & - & - & - & - & - & - & + & - & - & - & - \\
\hline+ & - & - & - & - & - & - & + & - & - & - & - \\
\hline- & + & - & - & - & - & - & + & - & - & - & - \\
\hline- & - & + & - & - & - & - & - & + & - & + & - \\
\hline- & - & + & + & - & - & - & - & - & - & + & - \\
\hline- & - & - & - & + & - & - & + & - & - & - & - \\
\hline- & - & - & - & - & + & - & - & - & - & - & - \\
\hline- & - & - & - & - & - & + & - & - & - & - & - \\
\hline- & - & - & - & - & - & - & + & - & - & - & - \\
\hline- & - & - & - & - & - & - & + & + & - & + & - \\
\hline- & - & - & - & - & - & - & - & - & + & - & - \\
\hline- & + & - & - & - & - & - & - & - & - & + & - \\
\hline- & - & - & - & - & - & - & - & - & - & - & + \\
\hline
\end{tabular}


$5,12,35,37,66$, and 79 isolates had $0,1,2,3,4,5$, and $6 A V R$ genes, respectively, based on their reactions on all 24 monogenic lines. Isolate 10-856-44 caused an $\mathrm{S}$ reaction on all 24 monogenic lines (Table 3), which suggested that the isolate contains none of the $24 A V R$ genes. Although six other isolates also had none of the $24 A V R$ genes, these isolates caused MS reactions (Fig. 1) on some monogenic lines; therefore, only isolate 10-856-44 was retained (Table 3). If a rice variety showed resistance to this isolate, the variety should contain at least one $R$ gene different from the $24 P i$ genes in the monogenic lines used.

After removing isolates with ambiguous reactions (MR or MS) (Fig. 1), an identity matrix with 37 preliminary candidate isolates and their alternatives was obtained after matrix transformation (Table 3).

Colony growth rate and conidia production of preliminary candidate isolates. The preliminary candidate isolates showed some variation in colony growth rate and conidiation (Table 3). By selecting isolates with a high growth rate and abundant conidial production, 25 isolates were selected as the final set of differential isolates and named as China Rice Blast (CRB) differential isolates 01 to 25 (i.e., CRB-01 to CRB-25) (Table 4). Most of these isolates have one to four $A V R$ genes in each isolate; however, CRB-15 had five while CRB-16 and CRB-17 both had six AVR genes (Table 4). Isolates CRB-12, CRB-13, CRB-14, CRB-19, CRB-20, and CRB-22 all had similar colony growth rates, slightly faster than the other isolates (Fig. 2B). In addition, the colony margins of CRB-04, CRB-10, CRB-13, and CRB-14 were more compact and the mycelia were whiter, while the mycelia of CRB-03, CRB-18, CRB-21, and CRB-25 were darker (Fig. 2A). The majority of differential isolates produced approximately $10^{5}$ to $10^{6}$ conidia/plate (Fig. 2C). These isolates could conveniently be cultured in the laboratory to produce spores for inoculation, which usually requires a concentration of $1 \times 10^{5}$ spores $/ \mathrm{ml}$ (Chi et al. 2009; Zhang et al. 2014).

Stability of pathogenic reaction type and conidiation for candidate isolates. The reaction patterns of the differential isolates were stable over a period of 3 years on the 24 monogenic lines in three tests, with no noticeable differences in pathotypes between the original isolates and their subcultures. The differential isolates also showed stable conidial production on OTA. A representative set of data is presented in Table 5 for four candidate isolates.

TABLE 5. Reaction patterns and conidiation of four differential isolates in several years ${ }^{\mathrm{a}}$

\begin{tabular}{|c|c|c|c|c|c|c|c|c|c|c|c|c|c|c|c|c|c|c|c|c|c|c|c|c|c|}
\hline Isolate & Pil & Pi11 & Pi12 & Pi19 & Pi20 & Pi3 & Pi5 & $\mathrm{Pi7}$ & $P i 9$ & Pia & $P i b$ & $P i i$ & Pik & $P i k^{h}$ & $P i k^{m}$ & $P i k^{p}$ & $P i k^{s}$ & Pish & Pit & Pita & Pita2 & $\mathrm{Piz}$ & $\mathrm{Piz}^{5}$ & $P i z^{t}$ & $\begin{array}{c}\log _{10} \\
\text { (conidiation) }\end{array}$ \\
\hline CRB-03(2015) & S & S & S & $\mathrm{S}$ & S & S & $\mathrm{S}$ & S & S & S & S & S & S & $\mathrm{S}$ & S & S & S & S & S & S & S & S & S & $\mathrm{R}$ & $6.53 \pm 0.06$ \\
\hline CRB-03(2016) & $\mathrm{S}$ & $\mathrm{S}$ & S & $\mathrm{S}$ & S & S & $\mathrm{S}$ & $\mathrm{S}$ & $\mathrm{S}$ & $\mathrm{S}$ & S & $\mathrm{S}$ & $\mathrm{S}$ & $\mathrm{S}$ & $\mathrm{S}$ & $\mathrm{S}$ & S & $\mathrm{S}$ & $\mathrm{S}$ & S & S & S & $\mathrm{S}$ & $\mathrm{R}$ & $6.69 \pm 0.10$ \\
\hline CRB-03(2017) & S & S & $\mathrm{S}$ & $\mathrm{S}$ & $S$ & S & $\mathrm{S}$ & S & S & S & S & $\mathrm{S}$ & $\mathrm{S}$ & $\mathrm{S}$ & S & S & S & S & S & S & $\mathrm{S}$ & S & S & $\mathrm{R}$ & $6.53 \pm 0.06$ \\
\hline CRB-09(2015) & S & $\mathrm{R}$ & S & S & S & S & $\mathrm{S}$ & S & S & S & S & S & S & S & S & S & S & S & S & S & $\mathrm{R}$ & $S$ & $\mathrm{R}$ & S & $5.81 \pm 0.23$ \\
\hline CRB-09(2016) & S & $\mathrm{R}$ & S & S & S & S & $\mathrm{S}$ & $S$ & $\mathrm{~S}$ & $S$ & $S$ & $\mathrm{~S}$ & S & $\mathrm{S}$ & S & S & S & $\mathrm{S}$ & S & S & $\mathrm{R}$ & $S$ & $\mathrm{R}$ & S & $6.04 \pm 0.10$ \\
\hline CRB-09(2017) & S & $\mathrm{R}$ & S & $\mathrm{S}$ & $\mathrm{S}$ & S & $\mathrm{S}$ & $S$ & $\mathrm{~S}$ & $S$ & $\mathrm{~S}$ & $\mathrm{~S}$ & $\mathrm{~S}$ & $\mathrm{~S}$ & $S$ & $S$ & S & S & S & $\mathrm{S}$ & $\mathrm{R}$ & $\mathrm{S}$ & $\mathrm{R}$ & S & $6.32 \pm 0.11$ \\
\hline CRB-10(2015) & S & S & S & $\mathrm{S}$ & S & S & $\mathrm{S}$ & S & $\mathrm{S}$ & S & S & S & S & $\mathrm{S}$ & S & S & $\mathrm{R}$ & $\mathrm{S}$ & S & S & $\mathrm{R}$ & $\mathrm{R}$ & S & S & $6.76 \pm 0.12$ \\
\hline CRB-10(2016) & S & S & S & $\mathrm{S}$ & S & S & $\mathrm{S}$ & S & S & $\mathrm{S}$ & S & $\mathrm{S}$ & $\mathrm{S}$ & $\mathrm{S}$ & S & $\mathrm{S}$ & $\mathrm{R}$ & $\mathrm{S}$ & S & S & $\mathrm{R}$ & $\mathrm{R}$ & S & S & $6.56 \pm 0.09$ \\
\hline CRB-10(2017) & S & $\mathrm{S}$ & $\mathrm{S}$ & S & S & $\mathrm{S}$ & $\mathrm{S}$ & $\mathrm{S}$ & $\mathrm{S}$ & $\mathrm{S}$ & $\mathrm{S}$ & $\mathrm{S}$ & $\mathrm{S}$ & S & $\mathrm{S}$ & S & $\mathrm{R}$ & $\mathrm{S}$ & S & S & $\mathrm{R}$ & $\mathrm{R}$ & $\mathrm{S}$ & S & $6.85 \pm 0.03$ \\
\hline CRB-12(2015) & S & $\mathrm{R}$ & S & S & S & $\mathrm{R}$ & $\mathrm{S}$ & $\mathrm{S}$ & S & S & $\mathrm{S}$ & $\mathrm{S}$ & $\mathrm{S}$ & $\mathrm{S}$ & $\mathrm{S}$ & S & S & $\mathrm{S}$ & S & S & $\mathrm{R}$ & $\mathrm{S}$ & S & S & $6.88 \pm 0.03$ \\
\hline CRB-12(2016) & S & $\mathrm{R}$ & S & $\mathrm{S}$ & S & $\mathrm{R}$ & $\mathrm{S}$ & S & $S$ & S & S & S & S & S & S & S & S & S & S & S & $\mathrm{R}$ & S & S & S & $6.44 \pm 0.07$ \\
\hline CRB-12(2017) & $\mathrm{S}$ & $\mathrm{R}$ & S & $\mathrm{S}$ & S & $\mathrm{R}$ & S & $\mathrm{S}$ & S & S & S & $\mathrm{S}$ & $S$ & S & S & S & S & S & $S$ & S & $\mathrm{R}$ & S & $S$ & S & $6.88 \pm 0.03$ \\
\hline
\end{tabular}

${ }^{a} \mathrm{R}=$ resistant and $\mathrm{S}=$ susceptible reaction. Lijiangxintuanheigu was susceptible to all of the tested isolates.
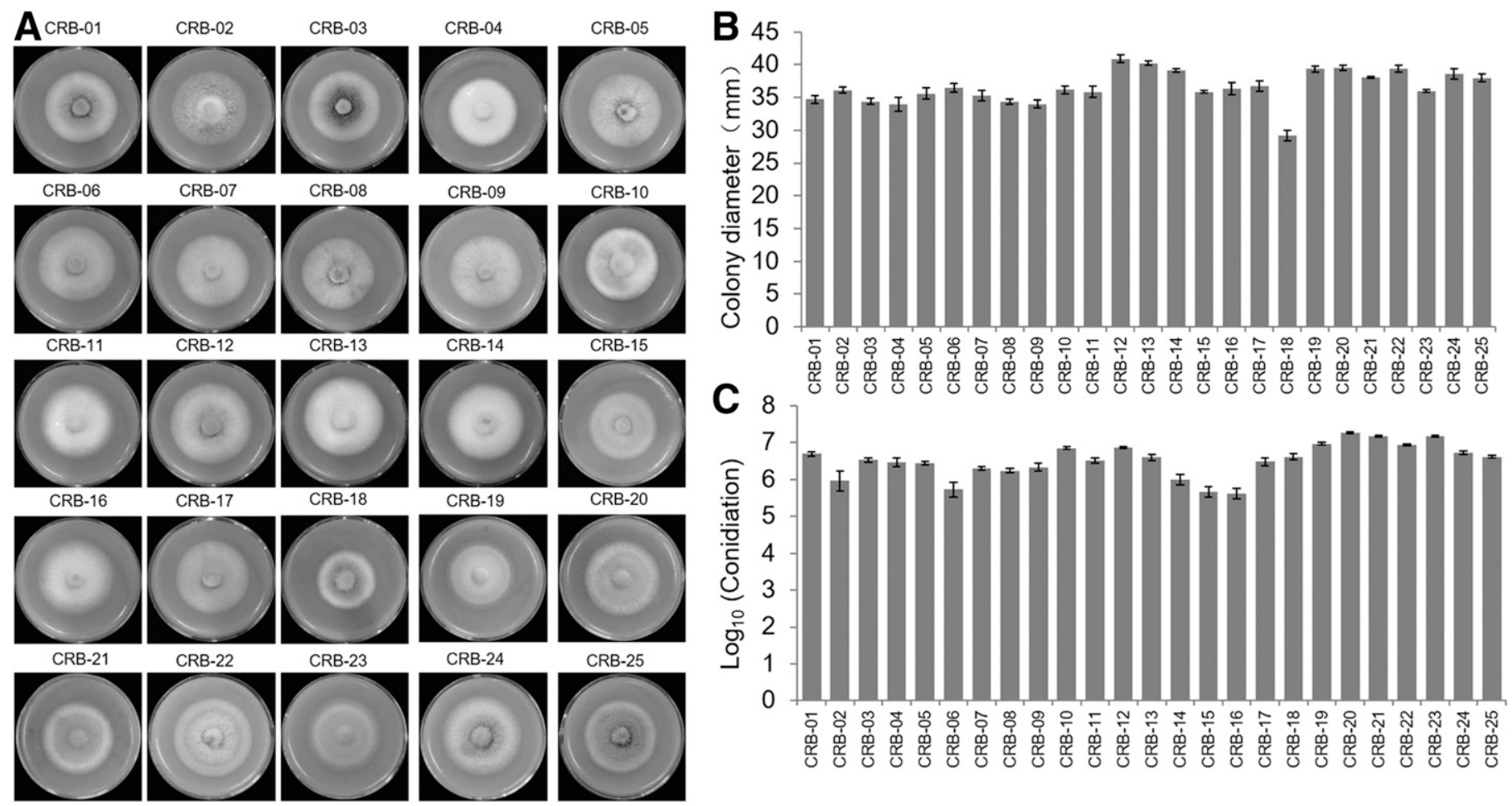

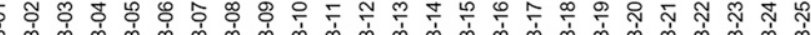

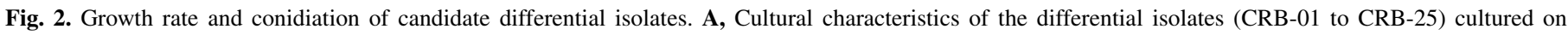

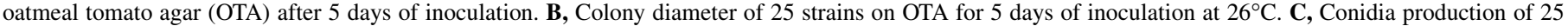
strains cultured on OTA for 7 days at $26^{\circ} \mathrm{C}$. Error bars represent standard errors of the mean. 


\section{DISCUSSION}

In the present study, 25 differential isolates were selected to establish a new set of differential isolates that would be stable over multiple years and retain high growth rates and high levels of conidial production. This was the first set of differential isolates that can stably differentiate combinations of all $24 P i$ genes and this is critical for a common set to be shared among researchers. Here, differential isolates exhibited consistency and stability in $A V R$ genotypes and conidiation, unlike some previous reports, where researchers found that isolates of $M$. oryzae were highly variable (Chadha and Sharma 2014; Roumen et al. 1997) and cited mechanisms of genetic variability in $M$. oryzae that included spontaneous mutations, heterokaryosis, and parasexual recombination (Genovesi and Magill 1976; Noguchi et al. 2006; Wu and Magill 1995). The difference between the previous studies and the current one might be attributable to the use of mycelium for serial transfer and storage in the current study, whereas conidia were usually used in the previous reports, where $M$. oryzae was found to be highly variable (Sharma et al. 2002). The current findings are consistent with those of Park et al. (2010), who indicated genetic stability of two isolates on an artificial medium and rice plants and observed no difference in cultural characteristics and pathogenicity (Latterell and Rossi 1986). The stability of the isolates might be attributable to the use of mycelium for serial transfer and storage in the current study, whereas conidia were usually used in the previous reports where $M$. oryzae was found to be highly variable (Sharma et al. 2002). Further studies are needed to confirm whether subculture via mycelium transfer and storage of mycelium on filter paper can ensure the stability of $M$. oryzae isolates, and whether reproduction via conidiation is a major source of variation for M. oryzae. The differential isolates and their subcultures also need to be tested periodically on the monogenic lines to ensure that their pathotypes remain the same and, perhaps, reisolated from the corresponding susceptible lines to avoid decline in pathogenicity.

Conventional polymerase chain reaction (PCR) is a good method to directly detect some $P i$ genes that are carried by a rice variety. This is usually conducted by genotyping, and many of the major blast $R$ genes also had been amplified in PCR. Given the complexity of repetitive sequences and transposon-like elements of genes, both upstream and downstream flanking sequences (Xue et al. 2012) should be sequenced. It is even more expensive to sequence the whole genomes of rice varieties, and laborious to have them assembled into contigs and placed into scaffolds. Therefore, within the foreseeable future, postulation of $R$ gene in rice varieties will still rely on inoculation with pathogen isolates carrying corresponding $A V R$ genes. Even we can detect an $R$ gene via a molecular method, if the gene functions under field conditions, it may still need to be confirmed by inoculation.

With this set of differential isolates, whether a rice cultivar had one or more of the $24 P i$ genes, and even additional blast $R$ genes, can be conveniently determined via wounding inoculation with these isolates. This will allow rapid and accurate postulation of the blast $R$ genes of commercial rice varieties compared with a traditional method, without inoculating the differential varieties. Ma et al. (2015) successfully postulated the major blast $R$ genes of 20 rice cultivars in Harbin by using an earlier set of 22 M. oryzae differential isolates named rice blast (RB) isolates RB01 to RB22, in which $13 R$ genes were detected, with Pia and Pi19 as the most prevalent. The results were consistent with amplification of corresponding $R$ genes via PCR. Jin et al. (2011) also analyzed $R$ genes of 98 rice varieties in Jilin Province using the 22 differential isolates. The number of $A V R$ genes was equal to or more than 5 in each of these $22 \mathrm{RB}$ differential isolates, while RB03 carried $19 A V R$ genes. This made postulation of blast $R$ genes complicated and, hence, the number of $A V R$ genes was purposefully and dramatically reduced in this new set of $\mathrm{CRB}$ differential isolates. We also expanded the ability of the differential isolates to detect different combinations of $24 P i$ genes. Ideally, to make postulation of $R$ genes quick and simple, each differential isolates should contain a single $A V R$ gene. However, only 5 of 1,377 field isolates were found with a single $A V R$ gene. More field isolates, especially more isolates from different regions and host plants, may be included in future screenings to ultimately obtain a set of differential isolates that each contain single unique $A V R$ gene.

If a variety were to show $R$ reactions to each of the 24 differential isolates, then the genotype of the variation would remain unknown. Longdao 5 has four $R$ genes (specifically, Piks, Pil, Pi19, and Pish) (Ma et al. 2015), although it may contain the other, unknown $R$ genes that are different from any of the 24 known $R$ genes. To date, 86 major rice blast genes have been characterized (Cesari et al. 2013; Huang et al. 2014). Therefore, a future goal is to develop a greater number of near-isogonic lines (Lei et al. 2014; TelebancoYanoria et al. 2010) to monitor new and emerging AVR genotypes in $M$. oryzae populations. In contrast, more field isolates from different regions and host plants may be included in future screenings to obtain a set of differential isolates that each contains a single unique $A V R$ gene and can postulate more than the current $24 R$ genes in rice varieties. Although far from perfect, this selection of 25 differential isolates will be useful in postulation of $R$ genes in varieties for control of rice blast via strategic deployment of $R$ genes (Zhu et al. 2000).

\section{LITERATURE CITED}

Bonman, J. M., Khush, G. S., and Nelson, R. J. 1992. Breeding rice for resistance to pests. Annu. Rev. Phytopathol. 30:507-528.

Cesari, S., Thilliez, G., Ribot, C., Chalvon, V., Michel, C., Jauneau, A., Rivas, S., Alaux, L., Kanzaki, H., Okuyama, Y., Morel, J. B., Fournier, E., Tharreau, D., Terauchi, R., and Kroj, T. 2013. The rice resistance protein pair RGA4/RGA5 recognizes the Magnaporthe oryzae effectors AVR-Pia and AVR1-CO39 by direct binding. Plant Cell 25:1463-1481.

Chadha, S., and Sharma, M. 2014. Transposable elements as stress adaptive capacitors induce genomic instability in fungal pathogen Magnaporthe oryzae. PLoS One 9:e94415.

Chi, M. H., Park, S. Y., Kim, S., and Lee, Y. H. 2009. A novel pathogenicity gene is required in the rice blast fungus to suppress the basal defenses of the host. PLoS Pathog 5:e1000401.

Choi, J., Park, S. Y., Kim, B. R., Roh, J. H., Oh, I. S., Han, S. S., and Lee, Y. H. 2013. Comparative analysis of pathogenicity and phylogenetic relationship in Magnaporthe grisea species complex. PLoS One 8:e57196.

Dai, Y. T., Jia, Y. L., Correll, J., Wang, X. Y., and Wang, Y. L. 2010. Diversification and evolution of the avirulence gene AVR-Pital in field isolates of Magnaporthe oryzae. Fungal Genet. Biol. 47:973-980.

Deng, Y. W., Zhai, K. R., Xie, Z., Yang, D. Y., Zhu, X. D., Liu, J. Z., Wang, X., Qin, P., Yang, Y. Z., Zhang, G. M., Li, Q., Zhang, J. F., Wu, S. Q., Milazzo, J., Mao, B. Z., Wang, E. T., Xie, H. A., Tharreau, D., and He, Z. H. 2017. Epigenetic regulation of antagonistic receptors confers rice blast resistance with yield balance. Science 355:962-965.

Genovesi, A. D., and Magill, C. W. 1976. Heterokaryosis and parasexuality in Pyricularia oryzae Cavara. Can. J. Microbiol. 22:531-536.

Hayashi, K., and Yoshida, H. 2009. Refunctionalization of the ancient rice blast disease resistance gene Pit by the recruitment of a retrotransposon as a promoter. Plant J. 57:413-425.

Huang, J., Si, W. N., Deng, Q. M., Li, P., and Yang, S. H. 2014. Rapid evolution of avirulence genes in rice blast fungus Magnaporthe oryzae. BMC Genet. 15:45.

Jeung, J. U., Kim, B. R., Cho, Y. C., Han, S. S., Moon, H. P., Lee, Y. T., and Jena, K. K. 2007. A novel gene, Pi40(t), linked to the DNA markers derived from NBS-LRR motifs confers broad spectrum of blast resistance in rice. Theor. Appl. Genet. 115:1163-1177.

Jin, C. P., Sun, G., Liu, J. L., Li, G. H., Zhang, S. H., and Pan, H. Y. 2011. Identification of rice varieties resistant to rice blast in Jilin province. Acta Agric. Boreali-Occident. Sin. 26:214-218.

Kobayashi, N., Yanoria, M. J. T., Tsunematsu, H., Kato, H., Imbe, T., and Fukuta, Y. 2007. Development of new sets of international standard differential varieties for blast resistance in rice (Oryza sativa L.). JARQ 41:31-37.

Latterell, F. M., and Rossi, A. E. 1986. Longevity and pathogenic stability of Pyricularia oryzae. Phytopathology 76:231-235.

Le, M. T., Arie, T., and Teraoka, T. 2010. Population dynamics and pathogenic races of rice blast fungus, Magnaporthe oryzae in the Mekong Delta in Vietnam. J. Gen. Plant Pathol. 76:177-182. 
Lei, C. L., Wang, J. L., Cheng, Z. J., Wang, J., and Zhao, Z. C. 2014. Advances in development of rice monogenic differentials for blast resistance. Crops 2: 5-8.

Levy, M., Correa-Victoria, F. J., Zeigler, R. S., Xu, S. Z., and Hamer, J. E. 1993. Genetic diversity of the rice blast fungus in a disease nursery in Colombia. Phytopathology 83:1427-1433.

Li, W., Wang, B. H., Wu, J., Lu, G. D., Hu, Y. J., Zhang, X., Zhang, Z. G., Zhao, Q., Feng, Q., Zhang, H. Y., Wang, Z. Y., Wang, G. L., Han, B., Wang, Z. H., and Zhou, B. 2009. The Magnaporthe oryzae avirulence gene AvrPiz- $t$ encodes a predicted secreted protein that triggers the immunity in rice mediated by the blast resistance gene Piz-t. Mol. Plant-Microbe Interact. 22:411-420.

Ling, Z. Z. 1984. Blast resistance classification of some rice varieties in China. Sci. Agric. Sin. 2:19-28.

Ling, Z. Z., Jiang, W. R., Pan, Q. H., and Li, M. F. 1990. Classification for blast resistance of some japonica type varieties from Yunnan province. Sci. Agric. Sin. 23:5-11.

Ling, Z. Z., Jiang, W. R., Wang, J. L., and Lei, C. L. 2001. Research and utilization of universally susceptible property of japonica rice variety Lijiangxintuanheigu. Sci. Agric. Sin. 34:116-117.

Ling, Z. Z., Lei, C. L., and Wang, J. L. 2004. Review and prospect for study of physiologic races on rice blast fungus (Pyricularia grisea). Sci. Agric. Sin. 37:1849-1859.

Liu, Y., Qi, X. S., Young, N. D., Olsen, K. M., Caicedo, A. L., and Jia, Y. L. 2015. Characterization of resistance genes to rice blast fungus Magnaporthe oryzae in a "Green Revolution" rice variety. Mol. Breed. 35:52.

Ma, J. T., Zhang, G. M., Xin, A. H., Zhang, L. Y., Deng, L. W., and Wang, Y. L. 2015. Resistance analysis of blast-resistance genes and resistance evaluation and utilization of rice varieties in Harbin. J. Plant Prot. 42: 160-168.

Noguchi, M. T., Yasuda, N., and Fujita, Y. 2006. Evidence of genetic exchange by parasexual recombination and genetic analysis of pathogenicity and mating type of parasexual recombinants in rice blast fungus, Magnaporthe oryzae. Phytopathology 96:746-750.

Odjo, T., Kawasaki-Tanaka, A., Noda, T., Ahohuendo, B. C., Sere, Y., Kumashiro, T., Yanagihara, S., and Fukuta, Y. 2014. Pathogenicity analysis of blast (Pyricularia oryzae Cavara) isolates from West Africa. JARQ 48: 403-412.

Ou, S. H. 1980. Pathogen variability and host resistance in rice blast disease. Annu. Rev. Phytopathol. 18:167-187.

Park, S. Y., Chi, M. H., Milgroom, M. G., Kim, H., Han, S. S., Kang, S., and Lee, Y. H. 2010. Genetic stability of Magnaporthe oryzae during successive passages through rice plants and on artificial medium. Plant Pathol. J. 26: 313-320.

Peng, Y. L., and Shishiyama, J. 1988. Temporal sequence of cytological events in rice leaves infected with Pyricularia oryzae. Can. J. Bot. 66:730-735.

Roumen, E., Levy, M., and Nottéghem, J. L. 1997. Characterisation of the European pathogen population of Magnaporthe grisea by DNA fingerprinting and pathotype analysis. Eur. J. Plant Pathol. 103:363-371.

Savary, S., Willocquet, L., Elazegui, F. A., Castilla, N. P., and Teng, P. S. 2000. Rice pest constraints in tropical Asia: Quantification of yield losses due to rice pests in a range of production situations. Plant Dis. 84:357-369.

Sharma, T. R., Chauhan, R. S., Singh, B. M., Paul, R., Sagar, V., and Rathour, R. 2002. RAPD and pathotype analyses of Magnaporthe grisea populations from the north-western Himalayan region of India. J. Phytopathol. 150: $649-656$
Shi, J., Li, D. Q., Li, Y., Li, X. Y., Guo, X. Y., Luo, Y. W., Lu, Y. G., Zhang, Q., Xu, Y. J., Fan, J., Huang, F., and Wang, W. M. 2015. Identification of rice blast resistance genes in the elite hybrid rice restorer line Yahui2115. Genome 58:91-97.

Su, J., Wang, W. J., Han, J. L., Chen, S., Wang, C. Y., Zeng, L. X., Feng, A. Q., Yang, J. Y., Zhou, B., and Zhu, X. Y. 2015. Functional divergence of duplicated genes results in a novel blast resistance gene Pi5O at the Pi2/9 locus. Theor. Appl. Genet. 128:2213-2225.

Takahashi, A., Hayashi, N., Miyao, A., and Hirochika, H. 2010. Unique features of the rice blast resistance Pish locus revealed by large scale retrotransposon-tagging. BMC Plant Biol. 10:175.

Telebanco-Yanoria, M. J., Koide, Y., Fukuta, Y., Imbe, T., Kato, H., Tsunematsu, H., and Kobayashi, N. 2010. Development of near-isogenic lines of Japonica-type variety Lijiangxintuanheigu as differentials for blast resistance. Breed. Sci. 60:629-638

Tsunematsu, H., Yanoria, M. J. T., Ebron, L. A., Hayashi, N., Ando, I., Kato, H., Imbe, T., and Khush, G. S. 2000. Development of monogenic lines for rice blast resistance. Breed. Sci. 50:229-234.

Valent, B. 1990. Rice blast as a model system for plant pathology. Phytopathology 80:33-36.

Valent, B., and Chumley, F. G. 1991. Molecular genetic analysis of the rice blast fungus, Magnaporthe grisea. Annu. Rev. Phytopathol. 29:443-467.

Wang, L., Hu, X. H., Lin, G., Zhao, D. M., Shi, J., Zhao, Z. X., Zeng, R., Li, H. J., Li, D. Q., Fan, J., Li, Y., Huang, F., and Wang, W. M. 2017. Expression-based genotyping of the rice blast resistance genes in the elite maintainer line Yixiang1B. Eur. J. Plant Pathol. 148:955-965.

Wilson, R. A., and Talbot, N. J. 2009. Under pressure: Investigating the biology of plant infection by Magnaporthe oryzae. Nat. Rev. Microbiol. 7: $185-195$

Wu, B. C., and Magill, C. W. 1995. Spontaneous mutations at fingerprint loci in clonal lineages of the rice blast fungus. Exp. Mycol. 19:86-90.

Xue, M. F., Yang, J., Li, Z. G., Hu, S. N., Yao, N., Dean, R. A., Zhao, W. S., Shen, M., Zhang, H. W., Li, C., Liu, L. Y., Cao, L., Xu, X. W., Xing, Y. F., Hsiang, T., Zhang, Z. D., Xu, J. R., and Peng, Y. L. 2012. Comparative analysis of the genomes of two field isolates of the rice blast fungus Magnaporthe oryzae. PLoS Genet. 8:e1002869.

Yang, J., Zhao, X. Y., Sun, J., Kang, Z. S., Ding, S. L., Xu, J. R., and Peng, Y. L. 2010. A novel protein Com1 is required for normal conidium morphology and full virulence in Magnaporthe oryzae. Mol. Plant-Microbe Interact. 23:112-123.

Zeigler, R. S., Leong, S. A., and Teng, P. S. 1994. Rice Blast Disease. CAB International, Wallingford, UK.

Zhang, H. F., Zheng, X. B., and Zhang, Z. G. 2016. The Magnaporthe grisea species complex and plant pathogenesis. Mol. Plant Pathol. 17:796-804.

Zhang, H. W., Fang, W. W., Liu, C. C., Zhao, W. S., and Peng, L. Y. 2014. Identification of Magnaporthe oryzae pathotypes by wounding inoculation of detached rice leaves. Plant Prot. 40:121-125.

Zhou, B., Qu, S. H., Liu, G. F., Dolan, M., Sakai, H., Lu, G. D., Bellizzi, M., and Wang, G. L. 2006. The eight amino-acid differences within three leucine-rich repeats between $\mathrm{Pi} 2$ and $\mathrm{Piz}$ - $t$ resistance proteins determine the resistance specificity to Magnaporthe grisea. Mol. Plant-Microbe Interact. 19:1216-1228.

Zhu, Y. Y., Chen, H. R., Fan, J. H., Wang, Y. Y., Li, Y., Chen, J. B., Fan, J. X., Yang, S. S., Hu, L. P., Leung, H., Mew, T. W., Teng, P. S., Wang, Z. H., and Mundt, C. C. 2000. Genetic diversity and disease control in rice. Nature 406:718-722. 